\title{
Physiological and isozyme alterations in lettuce seeds under different conditions and storage periods ${ }^{1}$
}

\author{
Hugo César Rodrigues Moreira Catão ${ }^{2 *}$, Luiz Antonio Augusto Gomes ${ }^{2}$, \\ Renato Mendes Guimarães ${ }^{2}$, Pedro Henrique Faria Fonseca ${ }^{2}$, Franciele Caixeta ${ }^{2}$, \\ Josué Clock Marodin ${ }^{3}$
}

\begin{abstract}
The objective of the study was to determine the physiological and isozyme alterations in lettuce seeds submitted to different conditions and storage periods. We used a completely randomized design with four replications in a factorial arrangement with six lettuce cultivars (Everglades, Babá de Verão, Elisa, Grand Rapids, Hortência and Salinas 88) and four storage periods $\left(30,60,90\right.$ and 120 days), on three storage rooms $\left(15,25\right.$ and $\left.35^{\circ} \mathrm{C}\right)$. The physiological quality was evaluated by first and final germination count, emergence, and germination and emergence speed indexes. The isoenzyme expression of catalase (CAT), esterase (EST), alcohol dehydrogenase (ADH) and malate dehydrogenase (MDH) were determined. The physiological quality of lettuce seeds was preserved when stored at $15^{\circ} \mathrm{C}$ room temperature. The high room temperatures associated with higher storage periods cause a reduction in physiological quality and alterations in enzymatic patterns of CAT, EST, ADH and MDH. For seeds stored at $15^{\circ} \mathrm{C}$, there were no physiological changes. The lettuce cultivars, especially Everglades, have different levels of tolerance to storage and isoenzyme expressions.
\end{abstract}

Index terms: Lactuca sativa, enzymes, storability, thermotolerance.

\section{Alterações fisiológicas e isoenzimáticas em sementes de alface em diferentes condições e períodos de armazenamento}

\begin{abstract}
RESUMO - O objetivo deste trabalho foi determinar alterações fisiológicas e isoenzimáticas em sementes de alface em diferentes condições e períodos de armazenamento. Utilizou-se o delineamento experimental inteiramente casualizado com quatro repetições, em arranjo fatorial com seis cultivares de alface (Everglades, Babá de Verão, Elisa, Grand Rapids, Hortência e Salinas 88) e quatro períodos de armazenamento (30, 60, 90 e 120 dias), em três ambientes de armazenamento (15, 25 e $\left.35{ }^{\circ} \mathrm{C}\right)$. A qualidade fisiológica foi avaliada por meio de testes de primeira e contagem final de germinação, emergência, índices de velocidade de germinação e de emergência. As expressões isoenzimáticas determinadas foram as de catalase (CAT), esterase (EST), álcool desidrogenase (ADH) e malato desidrogenase (MDH). As sementes de alface quando armazenadas em ambiente de $15{ }^{\circ} \mathrm{C}$ conservaram a qualidade fisiológica. As altas temperaturas do ambiente associada aos maiores períodos de armazenamento causam redução da qualidade fisiológica e alteração dos padrões enzimáticos de CAT, EST, ADH e MDH. No armazenamento a $15{ }^{\circ} \mathrm{C}$ não ocorreu alterações nas sementes. As cultivares de alface, especialmente Everglades, apresentam diferentes níveis de tolerância ao armazenamento e expressões isoenzimáticas.
\end{abstract}

Termos para indexação: Lactuca sativa, enzimas, potencial de armazenamento, termotolerância.

\section{Introduction}

Studying the expression of isoenzymes throughout the storage of seeds may be useful, since it allows the identification of variations related to abiotic factors. Hence, the use of biochemical markers becomes a tool to select materials that tolerate high temperatures, which is indispensable to develop

${ }^{1}$ Submitted on $05 / 12 / 2016$. Accepted for publication on $10 / 17 / 2016$. ${ }^{2}$ Departamento de Agricultura, Setor de Sementes, Universidade Federal de Lavras, Caixa Postal 3037, 37200-000 - Lavras, MG, Brasil. lettuce improvement programs (Lactuca sativa L.) for tropical and subtropical regions (Catão et al., 2014).

On tropical regions in general, the environmental conditions are adverse for the storage of seeds due to the high temperatures that may be associated with a high relative air humidity (Carvalho et al., 2014a). In addition to temperature, the relative air humidity of the storage room and the water 
content of the seed, the maintenance of their quality during storage is also influenced by the genotype (Martins-Filho et al., 2001). Therefore, the feasibility period of the seed depends on genetic characterizes and on environmental effects, and the interaction between these factors is determinant to preserve the seeds up to sowing (Gris et al., 2010).

A common practice among lettuce producers is, after sowing, they store the packages containing the rest of the seeds at inadequate locations, where the room temperature is usually high, which compromises the quality of the seeds for the next sowing. The rise in the temperature causes the endosperm to stiffen, and prevents root protrusion (Nascimento et al., 2012). According to Finch-Savage and Leubner-Metzger (2006), the dormancy in lettuce seeds is controlled by the genotype associated to: environmental factors, such as temperature; and physical factors, such as the thickness of the tegument. In addition, high temperatures accelerate the chemical reactions and intensify the deterioration metabolic processes. As a consequence of these metabolic events, the breathing of the seed promotes an increase on the deterioration speed, and one of the first degradation events is the loss of permeability of the membrane, since it loses its selectiveness, and enzymes and proteins become less efficient on catalytic activities (Smith and Berjak, 1995).

Enzymes have a fundamental role in several metabolic reactions both for the synthesis and for the biodegradation of molecules during the development and deterioration of the seed. Hence, some enzymes may be used as important biochemical markers. Among the enzymes used, esterase, catalase, superoxide dismutase, malate dehydrogenase, alcohol dehydrogenase, among others, have been used for feasibility studies, since they are efficient in order to get to know events related to the lifetime, deteriorative changes and the death of seeds (Basu, 1995). Thus, studying the enzymatic processes is one of the ways to evaluate the quality of seeds, even when there is a drop in reserves during storage at high temperatures (Marcos-Filho, 2005).

Hence, studies that relate different tolerance levels to high temperatures on lettuce cultivars during storage are scarce. Knowing the physiological quality and variations on the isozyme patterns may help to better understand the dormancy acquired by these seeds during storage. Thus, the objective of this study was to determine physiological and isozyme changes on lettuce seeds under different conditions and storage periods.

\section{Material and Methods}

The research was conducted on an experimental area in the municipality of Ijaci - MG and at the Central Laboratory of Seeds from the Agriculture Department of the Federal University of Lavras (UFLA), in Lavras, MG.

The production process of lettuce seeds was conducted in the municipality of Ijaci - MG between October 2011 and February 2012, on the area of Fazenda Palmital, located at latitude: $21^{\circ} 9^{\prime} 24^{\prime \prime}$ South, longitude 445' $34^{\prime \prime}$ West, where the soil is classified as an Oxisol with clayey texture.

Initially, the production of seedlings of the different lettuce cultivars was conducted: Everglades, Babá de Verão, Elisa (smooth leaf), Grand Rapids and Hortência (curly leaf) and Salinas 88 (crisp head). The seeds were sown on polystyrene trays with 128 cells containing the commercial substrate Multiplant-Hortaliças ${ }^{\circledR}$. After 21 days, the seedlings were transplanted to plats on a protected cultivated area.

A spacing of 0.4 meters between the plants and 0.6 between the rows was used, with six plants per plot on an area of $7.2 \mathrm{~m}^{2}$. The experimental design used randomized blocks with three replications, and the randomization was conducted in order to minimize possible environmental effects. During the seed production process, the maximum and minimum mean temperature of the air was measured one and a half meter from the soil, and they were, respectively, 45.6 and $31.2{ }^{\circ} \mathrm{C}$. The seeds from each plant of the same cultivar were individually collected within each block, and then they were homogeneously mixed constituting one single lot of seeds.

Then, the seeds of the six lettuce cultivars were treated with the Carboxin fungicide, before the initial evaluation of the quality and storage. The product was manually applied to the seeds, using plastic bags of a neutral chemical composition, and they were stirred up to their complete distribution. Then, the seeds of the different cultivars were submitted to the determination of the water content, and the evaluation was conducted according to Brasil (2009), and the results, expressed as a percentage.

The initial physiological quality of the seeds of the different lettuce cultivars produced was evaluated, aiming at characterizing them upon the following evaluations: Germination and initial counting: the sowing was conducted on two sheets of blotting paper, moistened in water, at a proportion of 2.5 the weight of the dry substrate, in gerbox plastic boxes. The boxes with the seeds were maintained on a BOD chamber at $20^{\circ} \mathrm{C}$ for the photoperiod of 12 hours. The evaluation was constituted by two counts of normal seedlings, four and seven days after installing the test (Brasil, 2009). Four subsamples of 50 seeds from each cultivar were analyzed, and the results were expressed as the percentage of normal seedlings. Emergence: sowing was conducted on gerbox plastic boxes, containing the commercial substrate Multiplant-Hortaliças ${ }^{\circledR}$, moistened up to $60 \%$ of the water retention capacity. The gerbox boxes were maintained on a BOD 
chamber at a temperature of $20{ }^{\circ} \mathrm{C}$, with a photoperiod of 12 hours. Four subsamples of 50 seeds from each cultivar were used and, after stabilizing the stand, the number of emerged seedlings was counted (Queiroz et al., 2011). Germination and emergence speed: the germination and emergence tests were simultaneously conducted, calculating the number of germinated seeds and the number of emerged seedlings daily and at the same time. Germinated seeds were considered as those with root protrusion, and emerged seedlings were those that had two completely opened folioles. The indexes were calculated according to the formula suggested by Maguire (1962).

After the initial characterization of the cultivars, the seeds from each one of the six lettuce cultivars were stored on individual Kraft paper packages and maintained on BOD chambers for a period of 30, 60, 90 and 120 days at temperatures of 15,25 and $35^{\circ} \mathrm{C}$. Then, the physiological quality was evaluated at each time and storage environment through the germination test, germination speed index and the emergence test. The tests were conducted as previously described.

The data were submitted to variance homogeneity analysis (Bartllet's test) and normality analysis (Lilliefors) and then they were transformed into $\sqrt{x+1}$. The data obtained in the initial characterization of cultivars were submitted to the analysis of variance and the means were compared using the test by Scott-Knott $(\mathrm{p}<0.05)$, following the completely randomized design. For the evaluation studies as to the physiological quality on the different environments and storage periods, the completely randomized design was used, with a $6 \times 4 \times 3$ factorial, whose factors were six lettuce cultivars, four storage periods and three storage environments, with four replications. Then, an analysis of variance was conducted for all tests, using the Sisvar statistical program (Ferreira, 2011), and the means were also compared using the test by ScottKnott, at 5\% probability.

The evaluation of the isozyme expression was also conducted at every period and storage environment, and two samples with 50 seeds were used per treatment. The seeds were grinded on a crucible, with liquid nitrogen and PVP (polyvinylpyrrolidone), and stored at $-86{ }^{\circ} \mathrm{C}$. In order to evaluate each isozyme, $100 \mathrm{mg}$ of the grinded powder were added to $250 \mu \mathrm{L}$ of extraction buffer (Tris HCL 0.2 M pH 8.0, $0.1 \%$ of $\beta$ - mercaptoethanol). Then, the samples were stirred on a vortex and kept on the fridge for one night. After this period, the samples were stirred on a vortex and centrifuged at $12,000 \mathrm{~g}$ for 30 minutes, at $4{ }^{\circ} \mathrm{C}$. The supernatant was transferred to microtubes, and the pellet, disposed.

The analyses were conducted using the NATIVA-PAGE electrophoresis technique on polyacrylamide gels, on a lot system (7.5\% separation gel and $4.5 \%$ concentration gel), using the gel
buffer/Tris-glycine pH 8.9 electrode system. An application of $60 \mu \mathrm{L}$ of the supernatant of the samples was conducted on the gel and the electrophoretic run was conducted at $120 \mathrm{~V}$ for five hours. At the end of the run, the gels were revealed for the enzymes catalase (CAT), esterase (EST), alcohol dehydrogenase $(\mathrm{ADH})$ and malate dehydrogenase $(\mathrm{MDH})$, according to Alfenas (2006). The isozyme patterns were evaluated considering the intensity of the bands, sing a white light transilluminator, model TFP-C/WL (Biosystems, Curitiba, PR).

\section{Results and Discussion}

The water content values of the seeds of the different cultivars, after drying, varied from 5.5 to $6.2 \%$. These percentages were also shown by Barbosa et al. (2011) on different lots of lettuce seeds. Regarding the initial physiological quality, all cultivars showed seeds with germination percentages above the standard used for commercialization of the species, which is $80 \%$ (Table 1 ).

Cultivars Elisa and Salinas 88 showed the lowest germination percentages and low vigor, obtained by the emergence test and by the germination and emergence speed indexes. Cultivar Everglades showed high physiological quality, as it may be observed on Table 1, and it was the one with the most vigor. According to Catão et al. (2014), on cultivar Everglades, the highest germination percentage was observed, even when the test was conducted under the influence of high temperatures. The high germination percentage and vigor are fundamental for the comparative study between cultivars under the influence of high temperatures. This is essential to determine the quality of the seeds and observe the effect of the treatment, and thus, define the materials that adjust the best to the thermal stress conditions.

Significant differences were also observed among the cultivars, storage periods and storage environments for the analyzed variables. The mean germination values (\%) of the seeds of lettuce cultivars stored at different environments and periods may be observed on Table 2 .

Regardless of the storage period, the environment at $15{ }^{\circ} \mathrm{C}$ preserved the quality of the seeds of all cultivars, similarly to the quality observed on the initial characterization of the seeds. The lettuce seeds are not influenced by external factors when stored on a cold chamber, which contributes to reduce the speed of deterioration processes (Nascimento et al., 2012). For the seeds stored at $25^{\circ} \mathrm{C}$, it was observed that from 60 days of storage, the quality of the seeds was compromised, except for the Everglades cultivar, which showed a high germination percentage. With the increase of the storage temperature to 35 ${ }^{\circ} \mathrm{C}$, an interference on the feasibility of the seeds of all lettuce cultivars occurred, except for Everglades (Table 2). Hence, the

Journal of Seed Science, v.38, n.4, p.305-313, 2016 
high temperature of the storage environment shows a major influence on the germination of lettuce seeds, compromising their quality. For Martins and Lago (2008), the high storage temperature has a major influence for the preservation of the seed, influencing the biochemical reactions that regulate its metabolism.

Table 1. Values for the initial germination count (IGC), final count (GER), germination speed index (GSI), emergence (E) and emergence speed index (ESI) for the initial characterization of the physiological quality of six lettuce cultivars.

\begin{tabular}{lccccc}
\hline \multicolumn{1}{c}{ Cultivars } & IGC (\%) & GER (\%) & GSI & E (\%) & ESI \\
\hline Babá de Verão & $96 \mathrm{~A}$ & $98 \mathrm{~A}$ & $31.7 \mathrm{C}$ & $91 \mathrm{~B}$ & $7.9 \mathrm{~B}$ \\
G. Rapids & $96 \mathrm{~A}$ & $97 \mathrm{~A}$ & $37.2 \mathrm{~B}$ & $88 \mathrm{~B}$ & $6.9 \mathrm{C}$ \\
Hortência & $98 \mathrm{~A}$ & $98 \mathrm{~A}$ & $41.9 \mathrm{~A}$ & $84 \mathrm{C}$ & $7.8 \mathrm{~B}$ \\
Salinas 88 & $87 \mathrm{~B}$ & $90 \mathrm{~B}$ & $22.9 \mathrm{D}$ & $80 \mathrm{C}$ & $7.4 \mathrm{~B}$ \\
Elisa & $78 \mathrm{C}$ & $82 \mathrm{C}$ & $18.5 \mathrm{E}$ & $78 \mathrm{C}$ & $6.4 \mathrm{D}$ \\
Everglades & $98 \mathrm{~A}$ & $99 \mathrm{~A}$ & $44.4 \mathrm{~A}$ & $98 \mathrm{~A}$ & $10.1 \mathrm{~A}$ \\
\hline \multicolumn{1}{c}{$\mathrm{CV}(\%)$} & 7.79 & 6.12 & 10.96 & 6.31 & 7.70 \\
\hline
\end{tabular}

${ }^{(1)}$ Means followed by the same uppercase letter on the column are not statistically different according to the Scott-Knott Test at $5 \%$ probability.

Table 2. Mean germination percentages for lettuce seeds stored at different periods and temperatures.

\begin{tabular}{|c|c|c|c|c|c|c|}
\hline \multirow{4}{*}{ Cultivars } & \multicolumn{6}{|c|}{ Storage periods (days) } \\
\hline & \multicolumn{3}{|c|}{30} & \multicolumn{3}{|c|}{60} \\
\hline & \multicolumn{6}{|c|}{ Storage temperatures $\left({ }^{\circ} \mathrm{C}\right)$} \\
\hline & 15 & 25 & 35 & 15 & 25 & 35 \\
\hline Babá de Verão & $96 \mathrm{Aa}$ & $93 \mathrm{Ba}$ & $70 \mathrm{Db}$ & $95 \mathrm{Aa}$ & $83 \mathrm{Bb}$ & $60 \mathrm{Cc}$ \\
\hline G. Rapids & $96 \mathrm{Aa}$ & $92 \mathrm{Ba}$ & $70 \mathrm{Db}$ & $95 \mathrm{Aa}$ & $73 \mathrm{Cb}$ & $53 \mathrm{Dc}$ \\
\hline Hortência & $97 \mathrm{Aa}$ & $94 \mathrm{Ba}$ & $88 \mathrm{Bb}$ & $94 \mathrm{Aa}$ & $76 \mathrm{Cb}$ & $62 \mathrm{Cc}$ \\
\hline Salinas 88 & $92 \mathrm{Ba}$ & $89 \mathrm{Ba}$ & $70 \mathrm{Db}$ & $88 \mathrm{Ba}$ & $59 \mathrm{Db}$ & $44 \mathrm{Ec}$ \\
\hline Elisa & $84 \mathrm{Ca}$ & $82 \mathrm{Ca}$ & $76 \mathrm{Cb}$ & $84 \mathrm{Ca}$ & $75 \mathrm{Cb}$ & $68 \mathrm{Bc}$ \\
\hline \multirow[t]{2}{*}{ Everglades } & $99 \mathrm{Aa}$ & $100 \mathrm{Aa}$ & $99 \mathrm{Aa}$ & $98 \mathrm{Aa}$ & $99 \mathrm{Aa}$ & $99 \mathrm{Aa}$ \\
\hline & \multicolumn{6}{|c|}{ Storage periods (days) } \\
\hline \multirow{3}{*}{ Cultivars } & & 90 & & & 120 & \\
\hline & \multicolumn{6}{|c|}{ Storage temperatures $\left({ }^{\circ} \mathrm{C}\right)$} \\
\hline & 15 & 25 & 35 & 15 & 25 & 35 \\
\hline Babá de Verão & $89 \mathrm{Ba}$ & $80 \mathrm{Bb}$ & $60 \mathrm{Bc}$ & $90 \mathrm{Ba}$ & $51 \mathrm{Cb}$ & $32 \mathrm{Cc}$ \\
\hline G. Rapids & $90 \mathrm{Ba}$ & $51 \mathrm{Db}$ & $28 \mathrm{Dc}$ & $88 \mathrm{Ba}$ & $42 \mathrm{Db}$ & $15 \mathrm{Dc}$ \\
\hline Hortência & $91 \mathrm{Ba}$ & $63 \mathrm{Cb}$ & $50 \mathrm{Cc}$ & $88 \mathrm{Ba}$ & $22 \mathrm{~Eb}$ & $11 \mathrm{Ec}$ \\
\hline Salinas 88 & $89 \mathrm{Ba}$ & $51 \mathrm{Db}$ & $18 \mathrm{Ec}$ & $85 \mathrm{Ca}$ & $17 \mathrm{~Eb}$ & $12 \mathrm{Ec}$ \\
\hline Elisa & $80 \mathrm{Ca}$ & $76 \mathrm{Ba}$ & $63 \mathrm{Bb}$ & $81 \mathrm{Ca}$ & $70 \mathrm{Bb}$ & $59 \mathrm{Bc}$ \\
\hline Everglades & $96 \mathrm{Aa}$ & $92 \mathrm{Ab}$ & $90 \mathrm{Ab}$ & $97 \mathrm{Aa}$ & $93 \mathrm{Ab}$ & $84 \mathrm{Ab}$ \\
\hline CV (\%) & & & & & & 3.89 \\
\hline
\end{tabular}

Test at $5 \%$ significance.

The temperature of $35^{\circ} \mathrm{C}$ helps to identify thermotolerant cultivars (Kozarewa et al., 2006; Catão et al., 2014), since high temperatures promote a high amount of mannose and galactose on the cellular wall of thermosensitive cultivars, causing the endosperm to stiffen and preventing the root protrusion (Nascimento et al., 2001).

According to Table 3, the germination speed index was influenced by the storage period and environment. As the room temperature increased from 15 to $35^{\circ} \mathrm{C}$, a decrease occurred on the germination speed for more susceptible cultivars (Table 3), which is in agreement with the paper by Villela et al. (2010). A decreased occurred for GSI also for Everglades; however, it is observed that this cultivar still shows the highest germination speeds throughout the storage period.

In relation to the emergence test (Table 4), it is pointed out that seeds stored across all storage periods, at a temperature of 25 and $35^{\circ} \mathrm{C}$, showed less vigor than those stored at $15^{\circ} \mathrm{C}$. Analyzing each cultivar, it is noticed that the room temperature 
reduced the vigor of the lettuce seeds. Only the Everglades cultivar showed greater tolerance to the thermal stress of the room; however, from 90 storage days, a reduction of its emergence is observed at temperatures of 25 and $35^{\circ} \mathrm{C}$. Similar results were observed by Ferreira et al. (2013), according to whom, the temperature of $33{ }^{\circ} \mathrm{C}$ affected the emergence and emergence speed of tomato seedlings. This is due to the fact that these temperatures affect the reorganization speed of cellular membranes, affecting the metabolism of the seeds and, thus, reducing the emergence speed of the seedlings.

Table 3. Germination speed index of lettuce seeds stored at different periods and temperatures.

\begin{tabular}{|c|c|c|c|c|c|c|}
\hline \multirow{4}{*}{ Cultivars } & \multicolumn{6}{|c|}{ Storage periods (days) } \\
\hline & \multicolumn{3}{|c|}{30} & \multicolumn{3}{|c|}{60} \\
\hline & \multicolumn{6}{|c|}{ Storage temperatures $\left({ }^{\circ} \mathrm{C}\right)$} \\
\hline & 15 & 25 & 35 & 15 & 25 & 35 \\
\hline Babá de Verão & $42.7 \mathrm{Ba}$ & $37.6 \mathrm{Cb}$ & $30.5 \mathrm{Ec}$ & $42.1 \mathrm{Aa}$ & $34.7 \mathrm{Bb}$ & $28.4 \mathrm{Cc}$ \\
\hline G. Rapids & $48.0 \mathrm{Aa}$ & $45.2 \mathrm{Ba}$ & $34.7 \mathrm{Db}$ & $36.1 \mathrm{Ba}$ & $31.2 \mathrm{Cb}$ & $23.0 \mathrm{Dc}$ \\
\hline Hortência & $46.9 \mathrm{Aa}$ & $44.9 \mathrm{Ba}$ & $43.2 \mathrm{Ba}$ & $40.9 \mathrm{Aa}$ & $37.2 \mathrm{Bb}$ & $28.3 \mathrm{Cc}$ \\
\hline Salinas 88 & $41.3 \mathrm{Ba}$ & $38.4 \mathrm{Ca}$ & $34.0 \mathrm{Db}$ & $37.8 \mathrm{Ba}$ & $28.2 \mathrm{Cb}$ & $21.4 \mathrm{Dc}$ \\
\hline Elisa & $37.2 \mathrm{Ca}$ & $37.6 \mathrm{Ca}$ & $37.6 \mathrm{Ca}$ & $23.1 \mathrm{Cb}$ & $34.0 \mathrm{Ba}$ & $32.3 \mathrm{Ba}$ \\
\hline \multirow[t]{2}{*}{ Everglades } & $48.7 \mathrm{Aa}$ & $48.6 \mathrm{Aa}$ & $48.7 \mathrm{Aa}$ & $41.9 \mathrm{Ab}$ & $46.8 \mathrm{Aa}$ & $42.3 \mathrm{Ab}$ \\
\hline & \multicolumn{6}{|c|}{ Storage periods (days) } \\
\hline \multirow{3}{*}{ Cultivars } & & 90 & & & 120 & \\
\hline & \multicolumn{6}{|c|}{ Storage temperatures $\left({ }^{\circ} \mathrm{C}\right)$} \\
\hline & 15 & 25 & 35 & 15 & 25 & 35 \\
\hline Babá de Verão & $32.4 \mathrm{Ba}$ & $22.4 \mathrm{Db}$ & $21.5 \mathrm{Cb}$ & $43.7 \mathrm{Ba}$ & $17.1 \mathrm{Cb}$ & $11.1 \mathrm{Cc}$ \\
\hline G. Rapids & $34.2 \mathrm{Ba}$ & $19.7 \mathrm{Db}$ & 7.4 Dc & $23.9 \mathrm{Da}$ & $18.6 \mathrm{Cb}$ & $4.9 \mathrm{Cc}$ \\
\hline Hortência & $34.1 \mathrm{Ba}$ & $30.6 \mathrm{Cb}$ & $19.9 \mathrm{Cc}$ & $40.8 \mathrm{Ca}$ & $10.6 \mathrm{Db}$ & $3.7 \mathrm{Cc}$ \\
\hline Salinas 88 & $33.2 \mathrm{Ba}$ & $22.1 \mathrm{Db}$ & 7.8 Dc & $38.0 \mathrm{Ca}$ & $6.4 \mathrm{~Eb}$ & $4.4 \mathrm{Cb}$ \\
\hline Elisa & $22.7 \mathrm{Ca}$ & $34.0 \mathrm{Bb}$ & $29.9 \mathrm{Bc}$ & $39.3 \mathrm{Ca}$ & $28.5 \mathrm{Bb}$ & $25.5 \mathrm{Bb}$ \\
\hline Everglades & $37.6 \mathrm{Ab}$ & $45.0 \mathrm{Aa}$ & $39.9 \mathrm{Ab}$ & $47.5 \mathrm{Aa}$ & $39.8 \mathrm{Ab}$ & $40.2 \mathrm{Ab}$ \\
\hline CV (\%) & & & & & & 7.03 \\
\hline
\end{tabular}

*Means followed by the same uppercase letter on the column and lowercase letter on the row are not statistically different according to the Scott-Knott Test at $5 \%$ significance.

It was observed several times that the high room temperatures, as well as the longer storage periods, compromise the quality of the lettuce seeds, reducing their feasibility. As the temperature increases, the metabolic processes on the seeds are accelerated, increasing their respiration and, consequently, the deterioration process (Marcos-Filho, 2005). The main changes related to the deterioration process are degradation and inactivation of enzymes (Copeland and McDonald, 2001), reduction of the respiratory activity (Ferguson et al., 1990) and loss of integrity of the cellular membranes (McDonald, 1999).

Evidences suggest that the high temperature causes oxidative stress, in which reactive oxygen species (ROS), such as the superoxide radical $\left(\mathrm{O}_{2}^{-}\right)$, hydroxyl $\operatorname{radial}(\mathrm{OH})$, hydrogen peroxide $\left(\mathrm{H}_{2} \mathrm{O}_{2}\right)$ and singlet oxygen $\left({ }^{1} \mathrm{O}_{2}\right)$, are produced (Jaleel et al., 2007). In order to eliminate these reactive species, the seeds show antioxidant enzymatic systems that constitute an important primary defense against the free radicals generated under stress conditions, such as superoxide dismutase (SOD), which catalyzes the dismutation of the superoxide radical into
$\mathrm{H}_{2} \mathrm{O}_{2}$ and $\mathrm{O}_{2}$, catalase (CAT) and ascorbate peroxidase (APX), which may break $\mathrm{H}_{2} \mathrm{O}_{2}$ into $\mathrm{H}_{2} \mathrm{O}$ and $\mathrm{O}_{2}$.

The high room temperatures associated to the storage periods caused changes on enzymatic patterns, especially for catalase (Figure 1). The activity of this enzyme was high for the Everglades and Salinas 88 cultivars; intermediate for Babá de Verão, Grand Rapids and Hortência; and the lowest activity was observed for Elisa. For Everglades, a reduction of the enzymatic activity of CAT occurred at the temperatures of 25 and $35^{\circ} \mathrm{C}$, after 120 storage days, corroborating the physiological quality results, which showed a reduction during the same period and temperatures. The higher germination and vigor percentages observed for Everglades may be related to the preservation of the antioxidant systems, offering protection against aging and deterioration of the seeds. The Elisa cultivar showed a reduction on the activity of this enzyme, which resulted on a reduced prevention of oxidative damages, and this may cause lower physiological quality. 
Table 4. Emergence percentage of lettuce seedlings from seeds stored at different periods and temperatures.

\begin{tabular}{|c|c|c|c|c|c|c|}
\hline \multirow{4}{*}{ Cultivars } & \multicolumn{6}{|c|}{ Storage periods (days) } \\
\hline & \multicolumn{3}{|c|}{30} & \multicolumn{3}{|c|}{60} \\
\hline & \multicolumn{6}{|c|}{ Storage temperatures $\left({ }^{\circ} \mathrm{C}\right)$} \\
\hline & 15 & 25 & 35 & 15 & 25 & 35 \\
\hline Babá de Verão & $94 \mathrm{Aa}$ & $87 \mathrm{Bb}$ & $73 \mathrm{Bc}$ & $90 \mathrm{Ba}$ & $86 \mathrm{Bb}$ & $48 \mathrm{Bc}$ \\
\hline G. Rapids & $91 \mathrm{Ba}$ & $78 \mathrm{Db}$ & $65 \mathrm{Cc}$ & $89 \mathrm{Ba}$ & $75 \mathrm{Cb}$ & $47 \mathrm{Bc}$ \\
\hline Hortência & $90 \mathrm{Ba}$ & $83 \mathrm{Cb}$ & $58 \mathrm{Dc}$ & $88 \mathrm{Ba}$ & $84 \mathrm{Bb}$ & $40 \mathrm{Cc}$ \\
\hline Salinas 88 & $91 \mathrm{Ba}$ & $81 \mathrm{Cb}$ & $54 \mathrm{Dc}$ & $87 \mathrm{Ba}$ & $75 \mathrm{Cb}$ & $41 \mathrm{Cc}$ \\
\hline Elisa & $93 \mathrm{Aa}$ & $82 \mathrm{Cb}$ & $55 \mathrm{Dc}$ & $93 \mathrm{Aa}$ & $83 \mathrm{Bb}$ & $50 \mathrm{Bc}$ \\
\hline \multirow[t]{2}{*}{ Everglades } & $96 \mathrm{Aa}$ & $95 \mathrm{Aa}$ & $93 \mathrm{Aa}$ & $97 \mathrm{Aa}$ & $93 \mathrm{Aa}$ & $95 \mathrm{Aa}$ \\
\hline & \multicolumn{6}{|c|}{ Storage periods (days) } \\
\hline \multirow{3}{*}{ Cultivars } & & 90 & & & 120 & \\
\hline & \multicolumn{6}{|c|}{ Storage temperatures $\left({ }^{\circ} \mathrm{C}\right)$} \\
\hline & 15 & 25 & 35 & 15 & 25 & 35 \\
\hline Babá de Verão & $87 \mathrm{Ba}$ & $68 \mathrm{Cb}$ & $36 \mathrm{Cc}$ & $78 \mathrm{Ca}$ & $50 \mathrm{Db}$ & $8 \mathrm{Cc}$ \\
\hline G. Rapids & $87 \mathrm{Ba}$ & $68 \mathrm{Cb}$ & $30 \mathrm{Dc}$ & $80 \mathrm{Ba}$ & $54 \mathrm{Cb}$ & $8 \mathrm{Cc}$ \\
\hline Hortência & $83 \mathrm{Ca}$ & $69 \mathrm{Cb}$ & $30 \mathrm{Dc}$ & $82 \mathrm{Ba}$ & $53 \mathrm{Cb}$ & $4 \mathrm{Cc}$ \\
\hline Salinas 88 & $87 \mathrm{Ba}$ & $63 \mathrm{Db}$ & $32 \mathrm{Dc}$ & $76 \mathrm{Ca}$ & $48 \mathrm{Db}$ & $6 \mathrm{Cc}$ \\
\hline Elisa & $91 \mathrm{Ba}$ & $75 \mathrm{Bb}$ & $40 \mathrm{Bc}$ & $83 \mathrm{Ba}$ & $72 \mathrm{Bb}$ & $28 \mathrm{Bc}$ \\
\hline Everglades & $96 \mathrm{Aa}$ & $83 \mathrm{Ab}$ & $85 \mathrm{Ab}$ & $94 \mathrm{Aa}$ & $81 \mathrm{Ab}$ & $79 \mathrm{Ab}$ \\
\hline
\end{tabular}

*Means followed by the same uppercase letter on the column and lowercase letter on the row are not statistically different according to the Scott-Knott Test at $5 \%$ significance.
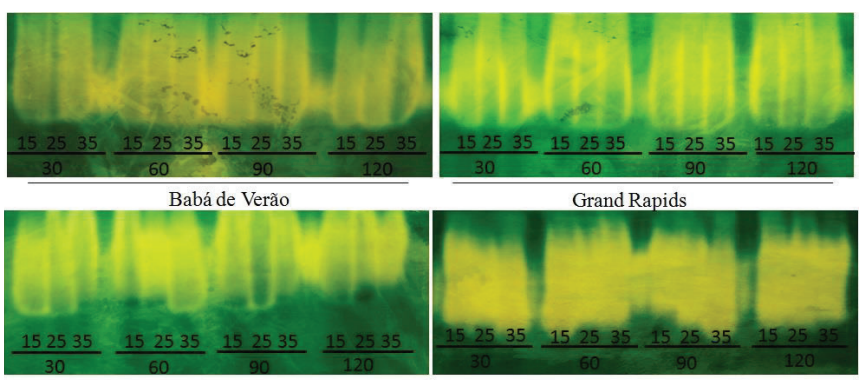

Hortência

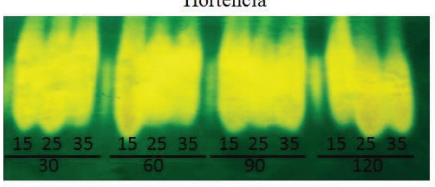

Everglades

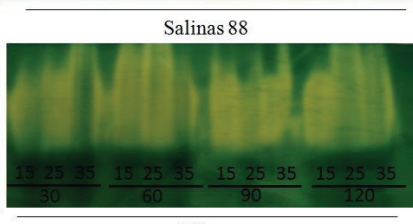

Figure 1. Isozyme expression of catalase (CAT) on the seeds of lettuce cultivars under different storage temperatures $\left(15,25\right.$ and $\left.35^{\circ} \mathrm{C}\right)$ and periods $(30$, 60,90 and 120 days).

The regulation of the antioxidant enzymes may be influenced (increased or even lost) due to the severity of the stress. If the activity is lost, it may considerably increase the production of free radicals that may trigger several events, starting with the peroxidation of lipids, proceeding with the degradation of membranes and cellular death (Greggains et al., 2000). Hence, the increase of the CAT activity is important to eliminate the accumulation of $\mathrm{H}_{2} \mathrm{O}_{2}$ resulting from the lipid peroxidation (Eyidogan and $\mathrm{Oz}, 2007$ ). For the Salinas 88 cultivar, the CAT activity remained high during the entire storage period, and this triggering of the antioxidant system upon thermal stress may be related to the smaller physiological amount of seeds.

Changes to the esterase expression (EST) are observed due to deteriorative events on the seeds (Figure 2). Cultivars such as Babá de Verão, Grand Rapids and Salinas 88 showed an increase on the activity of this enzyme as the period and the storage temperature increased. The activity of this enzyme showed different intensities on the Everglades and Elisa cultivars, which are the extremes regarding physiological quality. For the Elisa cultivar, the EST activity was higher when compared to the Everglades cultivar. It is noteworthy that esterase is an enzyme involved in hydrolysis reactions of esters and it is directly connected to the metabolism of lipids and to the degenerative process of membranes (Santos et al., 2004). The use of this enzyme was efficient as a biochemical marker for the quality of lettuce seeds when submitted to high temperatures.

Taylor (1997) reports that lettuce seeds are constituted by approximately $38 \%$ lipids, and the high oil content on these seeds favors the expression of these hydrolytic enzymes. Hence, the higher esterase activity at high storage temperatures 
indicates the beginning of the deteriorative process due to the loss of integrity of the membranes. In addition, the temperature increase may inactivate the expression of other enzymes that are connected to the germination process, since this condition leads to the stiffening of the endosperm and prevents root protrusion (Nascimento et al., 2012; Catão et al., 2014).
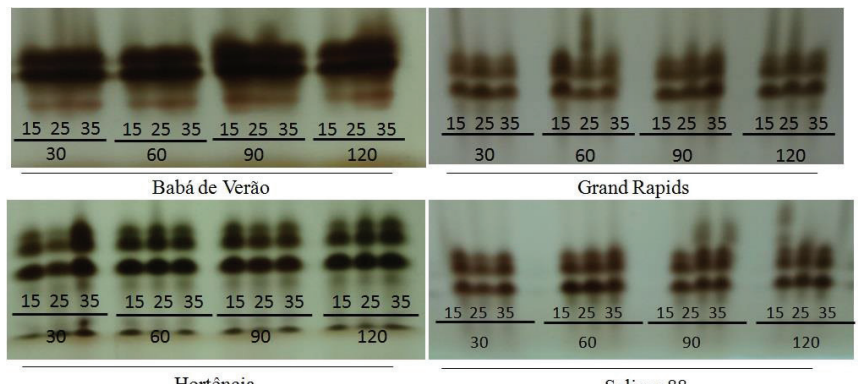

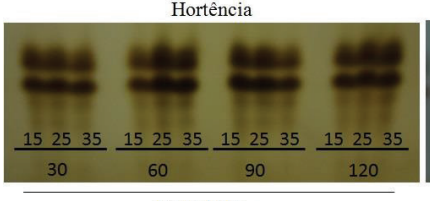

Everglades

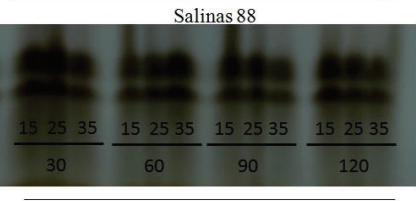

Elisa
Figure 2. Isozyme expression of esterase (EST) on the seeds of lettuce cultivars under different storage temperatures $\left(15,25\right.$ and $\left.35^{\circ} \mathrm{C}\right)$ and periods (30, 60, 90 and 120 days).

Among the cultivars, a difference occurred on the expression. Of the alcohol dehydrogenase (ADH) enzyme, with higher enzymatic activity on the seeds of Everglades and Babá de Verão, from 60 storage days (Figure 3). The ADH activity contributed to maintain the quality of the seeds of these cultivars on storage, even under adverse situations. Elisa showed an intermediate activity for the band standard when compared to Everglades and Babá de Verão. For the seeds of the Hortência, Salinas 88 and Grand Rapids cultivars, the $\mathrm{ADH}$ expression was lower. $\mathrm{ADH}$ is a relevant enzyme, since it converts acetaldehyde (a primary metabolite of the ethanol cycle on the conversion route to acetic acid) into ethanol, a compound with lower toxicity, and it reduces the speed of the deterioration process (Veiga et al., 2010). Thus, the seeds become less susceptible to the deleterious action of acetaldehyde with the higher ADH activity (Zhang et al., 1994). Carvalho et al. (2014b) observed greater ADH expressions on seeds from soy cultivars that showed greater physiological quality, which may be related to the maintenance of the germination metabolism of the seeds from the Everglades cultivar stored at high temperatures $\left(35^{\circ} \mathrm{C}\right)$ for 120 days (Table 2).
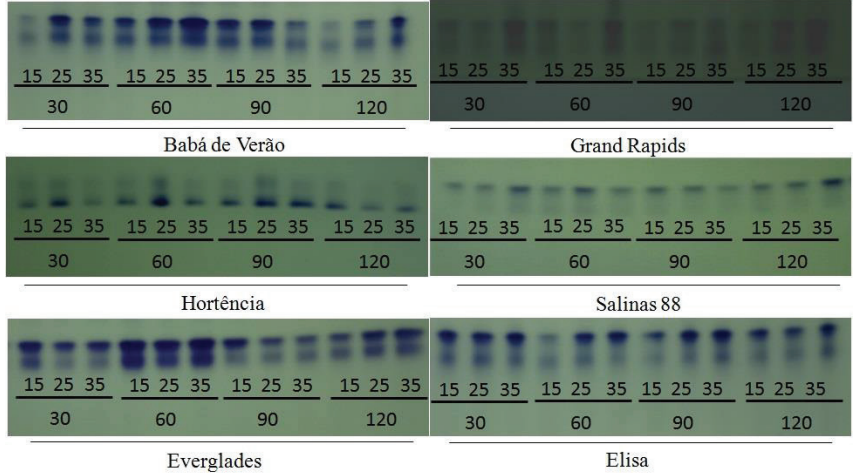

Figure 3. Isozyme expression of alcohol dehydrogenase $(\mathrm{ADH})$ on the seeds of lettuce cultivars under different storage temperatures $\left(15,25\right.$ and $\left.35{ }^{\circ} \mathrm{C}\right)$ and periods (30, 60, 90 and 120 days).

The isozyme profiles obtained on the lettuce seeds due to storage revealed, for malate dehydrogenase (MDH), that the highest activities were observed on cultivars Everglades, Babá de Verão and Elisa (Figure 4). Cultivars Grand Rapids, Hortência and Salinas 88 showed the same pattern under the storage conditions. For Everglades, it may be observed that MDH showed high activity under adverse conditions, and this increase on the activity was observed after 30 storage days at the temperature of $35^{\circ} \mathrm{C}$. The Elisa cultivar also showed high activity for this enzyme; however, this higher activity may be related to an accelerated respiration due to the low physiological quality of the seeds. It is noteworthy that MDH performs a significant role on the Krebs cycle, since it catalyzes the conversion of malate into oxaloacetate, producing $\mathrm{NADH}$, which is a fundamental product in the production of ATP. Thus, this enzyme is connected to the generation of energy for important metabolic processes, such as germination (Taiz and Zeiger, 2009). Thus, the seeds of the Everglades cultivar have a greater amount of energy, which assists on the germination process at high temperatures. The Elisa cultivar may have shown high respiration due to deterioration processes.

Based on the physiological and biochemical results discussed and shown, it is clear that the storage temperature is fundamental to preserve the quality of the lettuce seeds, since it acts on their feasibility, vigor and chemical reactions that determine the entire germination process. Another aspect to be pointed out is the use of EST and CAT enzymes as useful biochemical markers in studies on the physiological quality of lettuce seeds related to thermotolerance. 

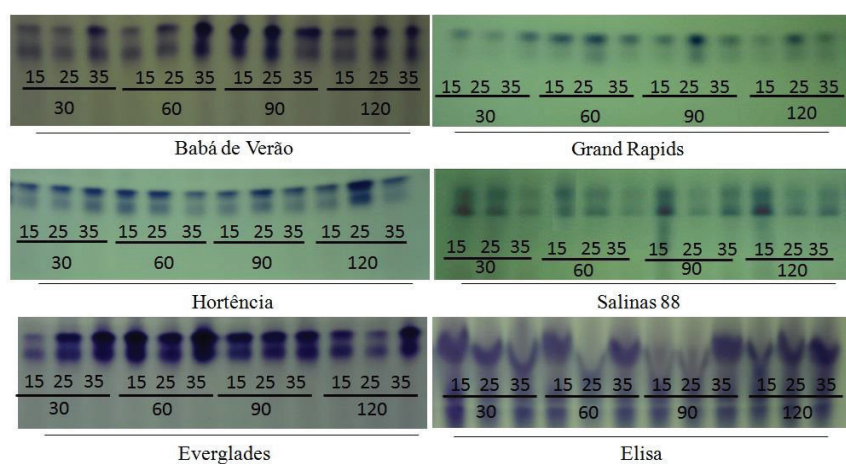

Figure 4. Isozyme expression of malate dehydrogenase $(\mathrm{MDH})$ on the seeds of lettuce cultivars under different storage temperatures $\left(15,25\right.$ and $\left.35^{\circ} \mathrm{C}\right)$ and periods (30, 60, 90 and 120 days).

\section{Conclusions}

The high room temperatures associated to longer storage periods cause changes to the physiological quality and to the isozyme patterns of lettuce seeds. Everglades shows tolerance to storage at high temperatures. The EST and CAT enzymes are useful as biochemical markers regarding the physiological quality of lettuce seeds.

\section{Acknowledgements}

To the National Council for Scientific and Technological Development (CNPq), to Minas Gerais Research Foundation (FAPEMIG), to the Federal University of Lavras (UFLA) and to HortiAgro Sementes S/A, for the financial support and for making this research possible.

\section{References}

ALFENAS, A.C. Eletroforese e marcadores bioquímicos em plantas e microrganismos. 2.ed. Viçosa: UFV, 2006. 627p.

BARBOSA, R.M.; COSTA, D.S.; SÁ, M.E. Envelhecimento acelerado em sementes de alface. Ciência Rural, v.41, n.11, p.1899-1902, 2011. http://www. scielo.br/scielo.php?script=sci_arttext\&pid=S0103-84782011001100008

BASU, R. N. Seed viability. In: BASRA, A. S. Seed quality: basic mechanisms and agricultural implications. New York: Haworth, 1995. p. 1-42.

BRASIL. Ministério da Agricultura, Pecuária e Abastecimento. Regras para análise de sementes. Ministério da Agricultura, Pecuária e Abastecimento. Secretaria de Defesa Agropecuária. Brasília: MAPA/ACS, 2009. 395p. http:// www.agricultura.gov.br/arq_editor/file/2946_regras_analise_sementes.pdf

CARVALHO, E.R.; MAVAIEIE, D.P.R.; OLIVEIRA, J.A.; CARVALHO, M.V.; VIEIRA, A.R. Alterações isoenzimáticas em sementes de cultivares de soja em diferentes condições de armazenamento. Pesquisa Agropecuária Brasileira, v.49, n.1, p.967-976, 2014a. http://www.scielo.br/pdf/pab/ v49n12/0100-204X-pab-49-12-00967.pdf
CARVALHO, E.R.; OLIVEIRA, J.A.; VON PINHO, E.V. R.; COSTA NETO, J. Enzyme activity in soybean seeds produced under foliar application of manganese. Ciênciae Agrotecnologia, v.38,n.4,p.317-327,2014b. http://www. scielo.br/scielo.php?script=sci_arttext\&pid=S1413-70542014000400001

CATÃO, H.C.R.M.; GOMES, L.A.A.; SANTOS, H.O.; GUIMARÃES, R.M.; FONSECA, P.H.F.; CAIXETA, F. Aspectos fisiológicos e bioquímicos da germinação de sementes de alface em diferentes temperaturas. Pesquisa Agropecuária Brasileira, v.49, n.4, p.316-322, 2014. http://www.scielo.br/ pdf/pab/v49n4/0100-204X-pab-49-04-0316.pdf

COPELAND, L.O.; MCDONALD, M.B. Principles of seed science and technology. 4th ed. New York: Chapman and Hall, 2001. 467p. http://link. springer.com/book/10.1007\%2F978-1-4615-1783-2

EYIDOGAN, F.; OZ, M.T. Effect of salinity on antioxidant responses of chickpea seedlings. Acta Physiology Plant, v.29, p.485-493, 2007. http://link. springer.com/article/10.1007\%2Fs11738-007-0059-9

FERGUSON, J. M.; TEKRONY, D. M.; EGLI, D. M. Changes during early soybean seed and axes deterioration: II., lipids. Crop Science, v.30, n.1, p.179182, 1990. https://dl.sciencesocieties.org/publications/cs/abstracts/30/1/ CS0300010179? access $=0$ \&view $=$ pdf

FERREIRA, D.F. Sisvar: a computer statistical analysis system. Ciência e Agrotecnologia, v.35, n.6, p.1039-1042, 2011. http://www.scielo.br/scielo. php?script=sci_arttext\&pid=S1413-70542011000600001

FERREIRA, R.L.; FORTI, V.A.; SILVA, V.N.; MELLO, S.C. Temperatura inicial de germinação no desempenho de plântulas e mudas de tomate. Ciência Rural, v.43, n.7, p.1189-1195, 2013. http://www.scielo.br/ scielo.php?script=sci arttext\&pid=S0103-84782013000700008

FINCH-SAVAGE, W.E.; LEUBNER-METZGER, G. Seed dormancy and the control of germination. New Phytologist, v.171, n.3, p.501-523, 2006. http:// onlinelibrary.wiley.com/doi/10.1111/j.1469-8137.2006.01787.x/pdf

GREGGAINS, V.; FINCH-SAVAGE, W.E.; QUICK, W.P.;ATHERTON, N.M. Metabolism-induced free radical activity does not contribute significantly to loss of viability in moist-stored recalcitrant seeds of contrasting species. New Phytologist, v.148, n 2, p.267-276, 2000. http://onlinelibrary.wiley.com/ doi/10.1046/j.1469-8137.2000.00757.x/epdf

GRIS, C.F.; VON PINHO, E.V. R.; ANDRADE, T.; BALDONI, A.; CARVALHO, M.L.M. Qualidade fisiológica e teor de lignina no tegumento de sementes de soja convencional e transgênica RR submetidas a diferentes épocas de colheita. Ciência e Agrotecnologia, v.34, n.2, p.374-381, 2010. http://www.scielo.br/scielo.php?script=sci_arttext\&pid=S1413$70542010000200015 \& \operatorname{lng}=$ en\&nrm $=$ iso\&tlng $=\mathrm{pt}$

JALEEL, C.A.; MANIVANNAN, P.; SANKAR, B.; KISHOREKUMAR, A.; GOPI, R.; SOMASUNDARUM, R.; PANNEERSELVAN, R. Water deficit stress mitigation by calcium chloride in Catharanthus roseus: effects on oxidative stress, praline metabolism and indole alkaloid accumulation. Colloids and Surfaces B: Biointerfaces, v.60, n.1, p.110-116, 2007. http:// www.sciencedirect.com/science/article/pii/S0927776507002470

KOZAREWA, I.; CANTLIFFE, D.J.; NAGATA, R.T.; STOFFELLA, P.J. High maturation temperature of lettuce seeds during development increased ethylene production and germination at elevated temperatures. Journal of the American Society of Horticultural Science, v.131, n.4, p.564-570, 2006. http://journal.ashspublications.org/content/131/4/564.full.pdf

MAGUIRE, J.D. Speed of germination - aid in selection and evaluation for seedling emergence and vigor. Crop Science, v.2, p.176-177, 1962. http:// www.scielo.br/scielo.php?script=sci_nlinks\&ref $=000106 \&$ pid $=$ S0100$6762200300050000100017 \& \operatorname{lng}=\mathrm{pt}$ 
MARCOS-FILHO, J. Fisiologia de sementes de plantas cultivadas. Piracicaba: FEALQ, 2005. 495p.

MARTINS, L.; LAGO, A.A. Conservação de semente de Cedrela fissilis: teor de água da semente e temperatura do ambiente. Revista Brasileira de Sementes, v.30, n.1, p.161-167, 2008. http://www.scielo.br/scielo. php?script $=$ sci_arttext\&pid=S0101-31222008000100020

MARTINS-FILHO, S.; LOPES, J.C.; RANGEL, O.J.P.; TAGLIAFERRE, C. Avaliação da qualidade fisiológica de sementes de soja armazenadas em condições de ambiente natural em Alegre-ES. Revista Brasileira de Sementes, v.23, n.2, p.201-208, 2001. http://www.abrates.org.br/revista/artigos/2001/ v23n2/artigo28.pdf

McDONALD, M. B. Seed deterioration: physiology, repair and assessment. Seed Science and Technology, v. 22, n. 3, p. 531-539, 1999. http://cat.inist. $\mathrm{fr} /$ ?aModele $=$ afficheN\&cpsidt $=1898410$

NASCIMENTO, W. M.; CANTLIFFE, D. J.; HUBER, D. J. Endobeta-mannanase activity and seed germination of thermosensitive and thermotolerant lettuce genotypes in response to seed priming. Seed Science Research, v.11, n.3, p.255-264, 2001. http://www.scielo.br/scielo. php?script=sci_arttext\&pid=S0103-90162004000200006

NASCIMENTO, W.M.; CRODA, M.D.; LOPES, A.C.A. Seed production, physiological quality and identification of thermotolerant lettuce genotypes. Revista Brasileira de Sementes, v. 34, n.3, p.510-517, 2012. http://www. scielo.br/scielo.php?script=sci arttext\&pid=S0101-31222012000300020

QUEIROZ, L.A.F.; VON PINHO, E.V. R.; OLIVEIRA, J.A.; FERREIRA, V. F.; CARVALHO, B.O.; BUENO, A.C.R. Época de colheita e secagem na qualidade de sementes de pimenta Habanero Yellow. Revista Brasileira de Sementes, v.33, n.3, p.472-481, 2011. http://www.scielo.br/scielo. php?script $=$ sci arttext\&pid $=$ S0101-31222011000300010
SANTOS, C. M. R.; MENEZES, N. L.; VILLELA, F. A. Alterações fisiológicas e bioquímicas em sementes de feijão envelhecidas artificialmente. Revista Brasileira de Sementes, v.26, n. 1, p. 110-119, 2004. http://www. scielo.br/scielo.php?script=sci_arttext\&pid=S0101-31222004000100017

SMITH, M. T.; BERJAK, P. Deteriorative changes associated with loss of viability of stored desiccation tolerant and desiccation-sensitive seeds. In: KIEGEL, J.;GALILI, G. (Ed.). Seed development and germination. New York: M. Dekker, 1995. p.701-746.

TAIZ, L.; ZEIGER, E. Fisiologia vegetal. Porto Alegre: Artmed, 2009. 719p.

TAYLOR, A. C. Seed storage, germination and quality. In: WIEN, H. C. (Ed.). The physiological of vegetable crops. New York: Wiley, 1997. p. 1-36.

VEIGA, A.D.; VON PINHO, E.V. R.; VEIGA, A.D.; PEREIRA, P.H. A.R.; OLIVEIRA, K.C.; VON PINHO, R.G. Influência do potássio e da calagem na composição química, qualidade fisiológica e na atividade enzimática de sementes de soja. Ciência e Agrotecnologia, v.34, n.4, p.953-960, 2010. http:// www.scielo.br/scielo.php?script=sci arttext\&pid=S141370542010000400022

VILLELA, R.P.; SOUZA, R.J.; GUIMARÃES, R.M.; NASCIMENTO, W.M.; GOMES, L.A.A.; CARVALHO, B.O.; BUENO, A.C.R. Produção e desempenho de sementes de cultivares de alface em duas épocas de plantio. Revista Brasileira de Sementes, v.32, n.1, p.158-169, 2010. http://www.scielo. $\mathrm{br} /$ scielo.php?script=sci arttext\&pid=S0101-31222010000100018\&lng=en \&nrm=iso\&tlng $=$ pt

ZHANG, M.; MAEDA, Y.; FUTIHATA, Y.; NORRAMURA, Y.I.; ESASHI, Y. A mechanism of seed deterioration in relation to volatile compounds evoked by dry seeds themselves. Seed Science Research, v.4, n.1, p.49-56, 1994. http://journals.cambridge.org/action/displayAbstract?fromPage $=$ online\&aid=1287676\&fileId=S0960258500001999 